\title{
Mold-Based Application of Laser-Induced Periodic Surface Structures (LIPSS) on Biomaterials for Nanoscale Patterning
}

Citation for published version (APA):

Hendrikson, W., Masman-Bakker, W., van Bochove, B., Skolski, J., Eichstadt, J., Koopman, B., van Blitterswijk, C., Grijpma, D., Romer, G-W., Moroni, L., \& Rouwkema, J. (2016). Mold-Based Application of Laser-Induced Periodic Surface Structures (LIPSS) on Biomaterials for Nanoscale Patterning. Macromolecular Bioscience, 16(1), 43-49. https://doi.org/10.1002/mabi.201500270

Document status and date:

Published: 01/01/2016

DOI:

10.1002/mabi.201500270

Document Version:

Publisher's PDF, also known as Version of record

\section{Document license:}

Taverne

Please check the document version of this publication:

- A submitted manuscript is the version of the article upon submission and before peer-review. There can be important differences between the submitted version and the official published version of record.

People interested in the research are advised to contact the author for the final version of the publication, or visit the DOI to the publisher's website.

- The final author version and the galley proof are versions of the publication after peer review.

- The final published version features the final layout of the paper including the volume, issue and page numbers.

Link to publication

\footnotetext{
General rights rights.

- You may freely distribute the URL identifying the publication in the public portal. please follow below link for the End User Agreement:

www.umlib.nl/taverne-license

Take down policy

If you believe that this document breaches copyright please contact us at:

repository@maastrichtuniversity.nl

providing details and we will investigate your claim.
}

Copyright and moral rights for the publications made accessible in the public portal are retained by the authors and/or other copyright owners and it is a condition of accessing publications that users recognise and abide by the legal requirements associated with these

- Users may download and print one copy of any publication from the public portal for the purpose of private study or research.

- You may not further distribute the material or use it for any profit-making activity or commercial gain

If the publication is distributed under the terms of Article $25 \mathrm{fa}$ of the Dutch Copyright Act, indicated by the "Taverne" license above, 


\title{
Mold-Based Application of Laser-Induced Periodic Surface Structures (LIPSS) on Biomaterials for Nanoscale Patterning ${ }^{a}$
}

\author{
Wim Hendrikson, ${ }^{\ddagger}$ Wendy Masman-Bakker, ${ }^{\ddagger}$ Bas van Bochove, \\ Johann Skolski, Justus Eichstädt, Bart Koopman, Clemens van Blitterswijk, \\ Dirk Grijpma, Gert-willem Römer, Lorenzo Moroni, Jeroen Rouwkema*
}

Laser-induced periodic surface structures (LIPSS) are highly regular, but at the same time contain a certain level of disorder. The application of LIPSS is a promising method to functionalize biomaterials. However, the absorption of laser energy of most polymer biomaterials is insufficient for the direct application of LIPSS. Here, we report the application of LIPSS to relevant biomaterials using a two-step approach. First, LIPSS are fabricated on a stainless steel surface. Then, the structures are replicated onto biomaterials using the steel as a mold. Results show that LIPSS can be transferred successfully using this approach, and that human mesenchymal stromal cells respond to the transferred structures. With this approach, the range of biomaterials that can be supplied with LIPSS increases dramatically.

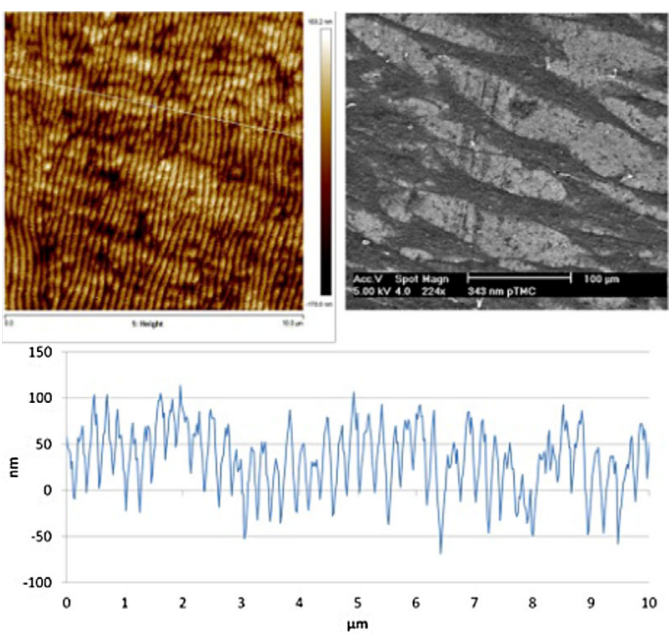

W. J. Hendrikson, Prof. C. A. van Blitterswijk, Dr. L. Moroni Department of Tissue Regeneration, MIRA Institute for Biomedical Technology and Technical Medicine, University of Twente, Enschede, 7500 AE, The Netherlands

W. D. Masman-Bakker, Prof. H. F. J. M. Koopman, Dr. J. Rouwkema Department of Biomechanical Engineering, MIRA Institute for Biomedical Technology and Technical Medicine, University of Twente, Enschede, $7500 \mathrm{AE}$, The Netherlands

E-mail: j.rouwkema@utwente.nl

J. B. van Bochove, Prof. D. W. Grijpma

Department of Biomaterials Science and Technology, MIRA Institute for Biomedical Technology and Technical

Medicine, University of Twente, Enschede, $7500 \mathrm{AE}$,

The Netherlands
Dr. J. Z. Skolski, Dr. J. Eichstädt, Dr. G. R. B. E. Römer Department of Applied Laser Technology, Faculty of Engineering Technology, University of Twente, Enschede, 7500 AE, The Netherlands

Prof. C. A. van Blitterswijk, Dr. L. Moroni

Complex Tissue Regeneration Department, MERLN Institute for Technology Inspired Regenerative Medicine, University of Maastricht, Maastricht, 6229 ER, The Netherlands Prof. D. W. Grijpma

Department of Biomedical Engineering, W. J. Kolff Institute, UMC Groningen, Groningen, 9700 AN,

The Netherlands

These authors contributed equally.

a Supporting Information is available online from the Wiley Online Library or from the author. 


\section{Introduction}

In recent years, it has become clear that micro- and nanoscale patterns on the surface of biomaterials have a profound effect on attachment, proliferation, migration, and differentiation of cells. ${ }^{[1,2]}$ In this aspect, especially grooves and ridges have been studied profoundly, since these patterns result in cellular alignment and directed migration, which is important for multiple biomedical processes such as myoblast fusion or axonal guidance, but also directed cellular differentiation. ${ }^{[3,4]}$

Laser-induced periodic surface structures (LIPSS) consist of highly regular wavy surface structures, or nanoripples, showing amplitudes and periodicity in the sub-micrometer range. ${ }^{[5,6]}$ LIPSS were first reported in 1965 by Birnbaum on semiconductors, ${ }^{[7]}$ but have also been observed on dielectrics, metals, and polymers. ${ }^{[8-13]}$ LIPSS are usually categorized based on their spatial periodicity $\Lambda$. When the spatial periodicity $\Lambda$ of the ripples is close to the wavelength $\lambda$ of the laser light used and the LIPSS are oriented orthogonal to the polarization of the laser light, the LIPSS are commonly referred to as "Low Spatial Frequency LIPSS" (LSFL). When a surface is exposed to ultra-short laser pulses, with pulse durations in the picosecond or femtosecond regime, the periodicity of LSFLs may be smaller than the wavelength of the laser. A second class of LIPSS shows a spatial periodicity which is smaller than the laser wavelength. These LIPSS are usually referred to as "High Spatial Frequency LIPSS" (HSFL) and are found on surfaces which are exposed to picosecondor femtosecond-pulsed laser radiation. A third class of LIPSS exhibits a spatial periodicity larger than the laser wavelength-i.e., $\Lambda>\lambda$, and are usually referred to as "Grooves." These Grooves are typically found on surfaces where a significant amount of material has been removed by laser ablation.

Here, we present a method to apply nanoscale ridges and grooves to biomaterial surfaces based on LIPSS. This method results in surface features that are highly organized, but at the same time contain a certain level of disorder, which was shown to be beneficial for directed cellular responses. ${ }^{[2,14-16]}$ Multiple studies have been reported where LIPSS were applied to metals like titanium in order to control the behavior of cells. ${ }^{[17-19]}$ Apart from that, LIPSS have been written directly on polystyrene for this purpose. ${ }^{[20-24]}$ In order to apply LIPSS directly to a biomaterial polymer surface, the linear absorption coefficient of the polymer for the specific wavelength used needs to be higher than $1 \times 10^{4} \mathrm{~cm}^{-1}$. ${ }^{25]}$ Therefore, these structures cannot be applied directly to many biomaterials that are generally used in tissue engineering and regenerative medicine. Here, we report the application of LIPSS to relevant polymeric biomaterials using a two-step moldbased approach.

\section{Results and Discussion}

\subsection{Application of LIPSS to Stainless Steel}

Homogeneously distributed LIPSS were successfully applied to $1.4 \times 1.4 \mathrm{~cm}^{2}$ areas on the stainless steel sheets. The direction of the LIPSS was perpendicular to the polarization of the laser radiation. A variation in the direction of the structures could be observed, with an interquartile distance of $13.1^{\circ}, 10.6^{\circ}$, and $13.7^{\circ}$, for structures created with a laser wavelength of 343,515 , and $1030 \mathrm{~nm}$, respectively, as determined by SEM (Figure $1 \mathrm{~A}$ and $3 \mathrm{C}$ ). The periodicity of the LIPSS was $220 \pm 26,298 \pm 51$, and $560 \pm 78 \mathrm{~nm}$ as determined by atomic force microscopy (AFM). This implies that the periodicity of the LIPSS were 64,58 , and $54 \%$ of the applied laser wavelength, respectively. The corresponding height of the LIPSS was $94.5 \pm 12,87.1 \pm 19$, and $148 \pm 34 \mathrm{~nm}$, respectively (Figure 1B and $2 \mathrm{~B}$ ).

It has been reported in the literature that the periodicity of LIPSS varies based on the material and the laser processing conditions -i.e., wavelength, number of pulses, and fluence applied. Periodicities as low as $30 \%$ of the wavelength of the laser have been observed for LIPSS applied to a titanium dioxide surfaces using both a 388 or $775 \mathrm{~nm}$ laser wavelengths, ${ }^{[19]}$ while periodicities are closer to the wavelength of the laser source for other materials such as titanium alloy Ti-6Al-4V (75\% when applying $\lambda=800 \mathrm{~nm})$, ${ }^{[17]}$ polystyrene (100\% when applying $\lambda=248 \mathrm{~nm}$; $80-95 \%$ when applying $\lambda=266 \mathrm{~nm}$ ), ${ }^{[26,21,23]}$ or poly(ethylene terephthalate) (83\% when applying $\lambda=157 \mathrm{~nm} ; 106 \%$ when applying $\lambda=265 \mathrm{~nm}) .{ }^{[27,28]}$ The values of this study are well within this reported range. Previously published heights of the structures are in the range of $15-130 \mathrm{~nm}$ for laser wavelengths in the range of $157-795 \mathrm{~nm} .^{[20,21,23,28,27]}$ The heights of resulting structures in this study are at the higher end of this range, especially for the laser wavelength of $1030 \mathrm{~nm}$. This is in accordance with previous literature, reporting higher features when a laser with a longer wavelength is used. ${ }^{[28]}$

\subsection{Replication of LIPSS to Biomaterials}

Since LIPSS cannot be directly applied to materials with a low absorption coefficient for the laser light used, this study explores a two-step approach to apply LIPSS to biomaterial surfaces. After applying LIPSS to a stainless steel sheet, the structures are replicated on the polymeric biomaterial using a mold-based approach.

Replication of LIPSS was attempted on the UV polymerizable biomaterials poly(trimethylene carbonate) (PTMC) and poly(ethylene glycol)-poly(trimethylene carbonate) (PEG-PTMC). LIPSS were replicated successfully to both these material (Figure 2). On PTMC networks, the periodicity 

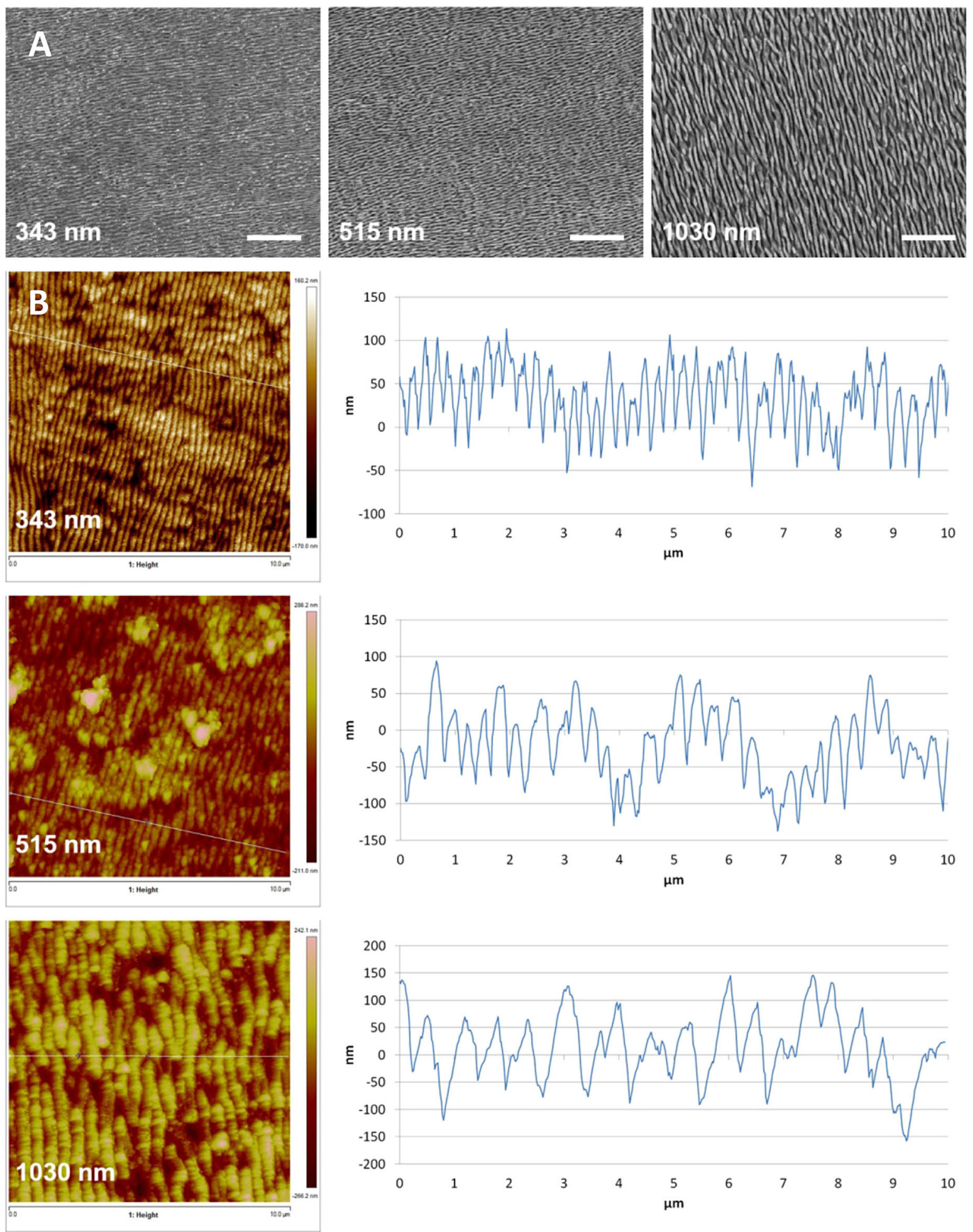

Figure 1. Characterization of applied LIPSS on steel molds by SEM (panel A, scale bar $5 \mu \mathrm{m}$ ) and AFM (panel B). The dimensions in the SEM and AFM figures refer to the laser wavelength. 
A

$343 \mathrm{~nm}$

$515 \mathrm{~nm}$

$1030 \mathrm{~nm}$
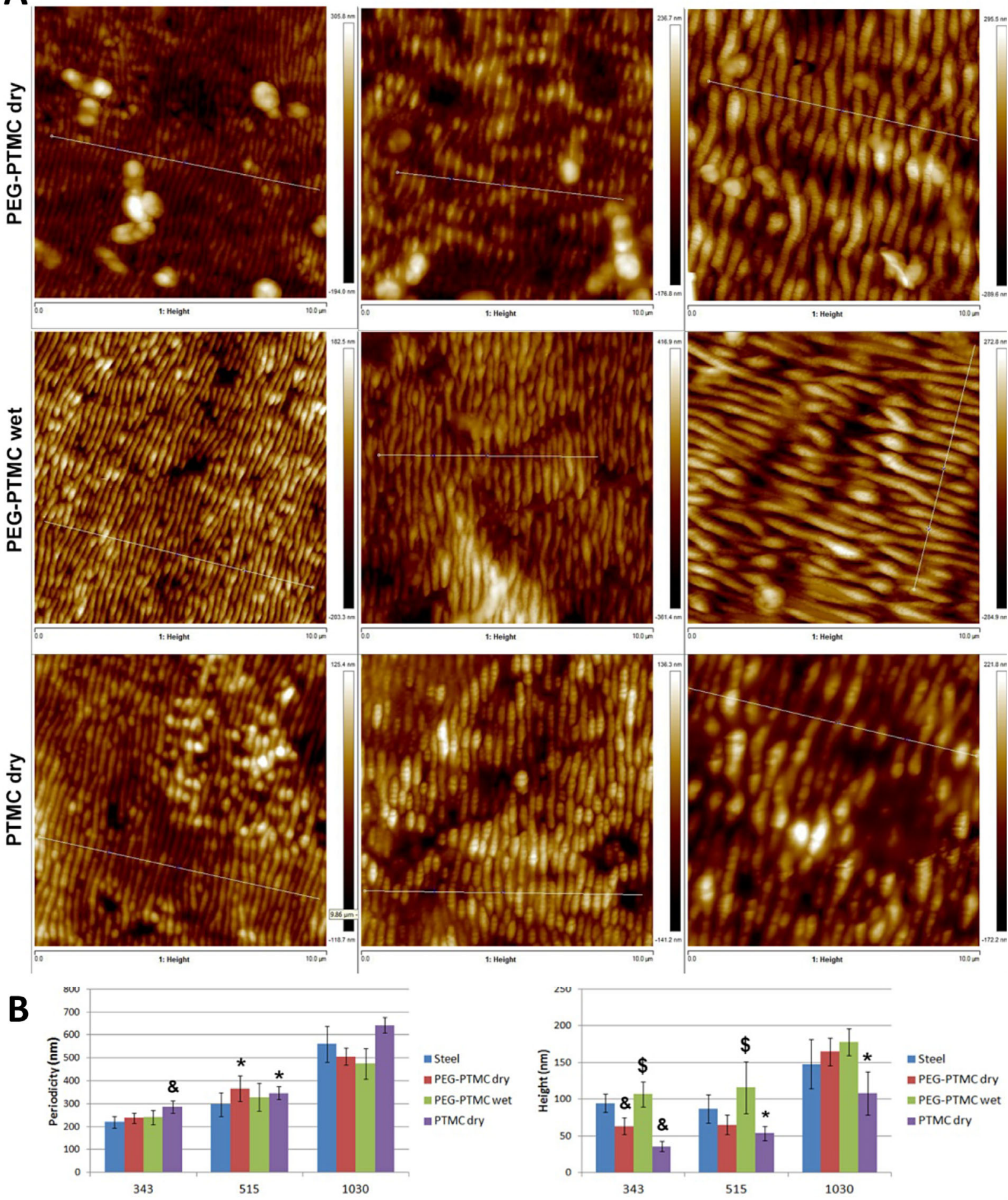

Figure 2. Replication of LIPSS on PEG-PTMC and PTMC networks as characterized by AFM (panel A). Corresponding height profiles are displayed in Figure S1. The height and periodicity of the resulting features were quantified and compared to the steel molds (panel B. $n=7$; ${ }^{*} p<0.05 ; \& p<0.005$ compared to steel; $\$ p<0.005$ compared to dry PEG-PTMC networks). 
of the LIPSS was $286 \pm 27,346 \pm 27$, and $643 \pm 33 \mathrm{~nm}$, and the corresponding height of the LIPSS was $35.7 \pm 6.8$, $53.8 \pm 9.6$, and $108 \pm 29 \mathrm{~nm}$ for structures prepared with a 343,515 , and $1030 \mathrm{~nm}$ laser wavelength, respectively, as determined by AFM (Figure S1). This means that compared to the LIPSS on steel, the structures were significantly lower in height. Apart from that, the periodicity was significantly higher for the samples prepared with the 343 and $515 \mathrm{~nm}$ wavelength.

On PEG-PTMC networks, the periodicity of the LIPSS was $237 \pm 23,365 \pm 56$, and $506 \pm 37 \mathrm{~nm}$, and the corresponding height of the LIPSS was $63.3 \pm 11,65.3 \pm 13$, and $165 \pm 19 \mathrm{~nm}$ for structures prepared with a $\lambda=343 \mathrm{~nm}$, $\lambda=515 \mathrm{~nm}$, and $\lambda=1030 \mathrm{~nm}$ laser wavelength, respectively, as determined by AFM. This means that compared to the LIPSS on steel, the structures were significantly lower in height only for the samples prepared with $\lambda=343 \mathrm{~nm}$. Apart from that, the periodicity was significantly higher for the samples prepared with $\lambda=515 \mathrm{~nm}$ radiation.

Since PEG-PTMC networks swell considerably in a wet environment, the effect of swelling of this material on the topography of the LIPSS was determined. On wet PEGPTMC, the periodicity of the LIPSS was $241 \pm 32,329 \pm 60$, and $474 \pm 66 \mathrm{~nm}$, and the corresponding height of the LIPSS was $107 \pm 17,116 \pm 35$, and $177 \pm 18 \mathrm{~nm}$ for structures prepared with a 343, 515, and $1030 \mathrm{~nm}$ wavelength, respectively, as determined by AFM. This means that compared to the LIPSS on steel, there were no statistical differences regarding periodicity or height. When compared to the dry PEG-PTMC networks, there were no statistical differences regarding the periodicity. Regarding the height of the LIPSS though, the structures were significantly higher for the samples prepared with the 343 and $515 \mathrm{~nm}$ lasers.

It is unclear what caused the differences in periodicity of the replicated LIPSS compared to the LIPSS on steel. This may be related to a slight expansion of the material after removal from the steel mold. When comparing the profiles of the LIPSS on PTMC networks, it can be seen that the structures have less sharp peaks and are rounded off compared to the LIPSS on steel and PEG-PTMC networks. Combined with the significantly lower height of the structures on PTMC networks, this indicates that PTMC does not fill the structures on steel completely upon replication.

It is known that the application of LIPSS to material surfaces changes the chemical properties of these surfaces. ${ }^{[20,24,29]}$ Cells grown on materials with applied LIPSS will therefore not only be affected by changes in surface topography, but also changes in surface chemistry. Due to the indirect application of LIPSS to biomaterial surfaces using a mold as presented here, this effect is minimized. Even though further research is necessary to assess whether the mold changes the biomaterial surface by for instance depositing metal residues, it is likely that the presented method only changes the surface topography.

\subsection{Cell Culture}

Human mesenchymal stromal cells (hMSC) were cultured successfully on both patterned PTMC and PEG-PTMC networks for up to $4 \mathrm{~d}$. Methylene blue staining showed regions with a higher cell density on PTMC networks, regardless of the LIPSS on the surface. This is most likely due to some crumpling of the sheets, resulting in non-uniform initial cell seeding (Figure 3A).

ImageJ analysis showed that the cells preferentially organized into a certain direction on both materials for all three wavelengths. A variation in the direction of the cells could be observed, with an interquartile distance of $42.5^{\circ}, 32.4^{\circ}$, and $28.3^{\circ}$, for structures prepared on PTMC networks, and $39.1^{\circ}, 34.1^{\circ}$, and $30.1^{\circ}$, for structures prepared on PEG-PTMC networks, with $\lambda=343 \mathrm{~nm}$, $\lambda=515 \mathrm{~nm}$, and $\lambda=1030 \mathrm{~nm}$ wavelength laser, respectively (Figure $3 \mathrm{C}$ ). The control, non-patterned samples, showed an interquartile distance of $87.9^{\circ}$ for PTMC and $89.9^{\circ}$ for PEG-PTMC, which is close to the theoretical $90^{\circ}$ for perfectly random-oriented cells. SEM analysis showed that the alignment of the cells was in the direction of the LIPSS for all three wavelengths used (Figure 3B).

Even though the cells align on both materials and on LIPSS produced with all three wavelengths, the alignment increases with an increase in the wavelength of the laser used to fabricate the LIPSS. Given the differences between the periodicity and height of the structures prepared with the different laser wavelengths, this indicates that within the framework of this study, hMSC respond better to surface structures that have a higher value for the periodicity, even though an additional effect of other factors such as the height or regularity of the structures cannot be ruled out.

The exact mechanism by which the cells sense and respond to LIPSS remains unclear. It has been reported that cells can align on ridges as narrow as $70 \mathrm{~nm}$ and as low as $35 \mathrm{~nm},{ }^{[30,31]}$ but it is unclear whether cells recognize and respond to the topography directly, or whether the topography prompts a pattern in the distribution of adhesive proteins, which then affects the materialcytoskeleton crosstalk. ${ }^{[31]}$ However, given the small size of the structures that cells can respond to, it is unlikely that the cell membrane can bend into the nanostructures to closely follow the material profile, or that the structures distort the organization of actin filaments in the cell cytoskeleton directly. ${ }^{[23]}$ In contrast, recent findings show that the response of cells to nanofeatures is tightly linked with the formation and dynamics of focal adhesions on the ridges of the structures, which in turn modulates cytoskeletal reorganization and cell function. ${ }^{[2,32]}$

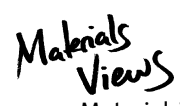

www.MaterialsViews.com

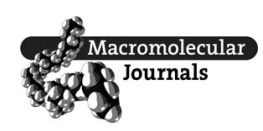



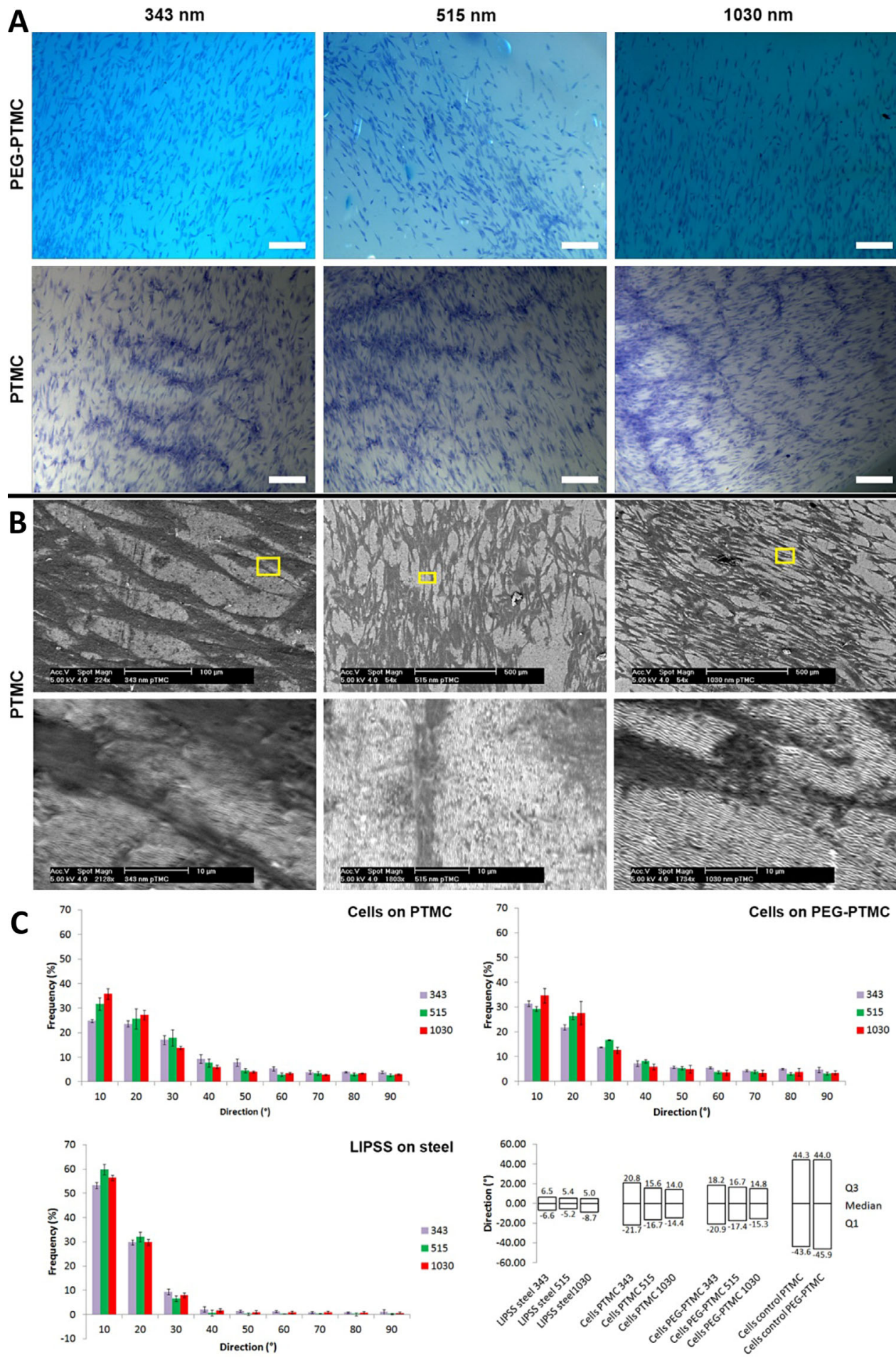

Figure 3. hMSC cultured on the patterned biomaterials for $4 \mathrm{~d}$. Cells were stained with methylene blue for phase contrast imaging (panel A, scale bar $50 \mu \mathrm{m}$ ) or processed for SEM analysis (panel B. The bottom image of this panel is a magnification of the region denoted by the yellow square in the upper image). Using the methylene blue images, the alignment of the cells was quantified and compared with the alignment of the features on the steel mold as determined using SEM. The frequency of features within a certain deviation from the main alignment direction is displayed (panel C. $n=3$ ). The bottom right graph displays the interquartile range for all groups to better illustrate the differences in distribution. 


\section{Conclusion}

In conclusion, we show that by using a mold-based approach, LIPSS can be applied to biomaterials. As a result, this novel method enables the application of nanoscale structures that are highly organized, but at the same time contain a certain level of disorder, which was shown to be beneficial for directed cellular responses, ${ }^{[2,14-16]}$ to a wider range of biomaterials. Given the current focus in the field on nanotopography as a promising method to control cellular niches and cellular behavior, ${ }^{[2]}$ we believe that this method provides an interesting new tool for stem cell biology and applications in the regenerativemedicine field.

Acknowledgements: J. R. was financially supported by a VENI grant by the Dutch Technology Foundation STW, and by the People Programme (Marie Curie Actions) of the European Union's Seventh Framework Programme (FP7/2007-2013) under REA grant agreement no. 622294.

Received: July 16, 2015; Revised: August 19, 2015; Published online: September 3, 2015; DOI: 10.1002/mabi.201500270

Keywords: human mesenchymal stromal cells; laser-induced periodic surface structures; nanoscale; polymeric biomaterials

[1] K. Kolind, K. W. Leong, F. Besenbacher, M. Foss, Biomaterials 2012, 33, 6626

[2] M. J. Dalby, N. Gadegaard, R. O. Oreffo, Nat. Mater. 2014, 13, 558.

[3] E. K. Yim, S. W. Pang, K. W. Leong, Exp. Cell Res. 2007, 313, 1820.

[4] M. R. Lee, K. W. Kwon, H. Jung, H. N. Kim, K. Y. Suh, K. Kim, K. S. Kim, Biomaterials 2010, 31, 4360.

[5] G. R. B. E. Römer, J. Z. P. Skolski, J. Vincenc Obona, V. Ocelik, J. T. M. Hosson, A. J. Huis in 't Veld, in Laser-Based Micro- and Nanoprocessing VIII, San Francisco, California, USA 2014.

[6] J. Z. P. Skolski, "Modeling of Laser-Induced Periodic Surface Structures - an Electromagnetic Approach", PhD Thesis, University of Twente, Enschede, The Netherlands 2014.

[7] M. Birnbaum, J. Appl. Phys. 1965, 36, 3688.
[8] P. A. Temple, M. J. Soileau, IEEE J. Quantum Electron. 1981, 17, 2067.

[9] M. Siegrist, G. Kaech, F. K. Kneubühl, Appl. Phys. A 1973, 2, 45.

[10] Y. Jee, M. F. Becker, R. M. Walser, J. Opt. Soc. Am. 1988, 5, 648.

[11] J. S. Young, H. M. V. D. Preston, J. E. Sipe, Phys. Rev. B 1983, 27, 1155.

[12] S. Baudach, J. Bonse, W. Kautek, Appl. Phys. A 1999, 69, 395.

[13] M. Csete, S. Hild, A. Plettl, P. Ziemann, Z. Bor, O. Marti, Thin Solid Films 2004, 453-454, 114.

[14] M. J. Dalby, N. Gadegaard, R. Tare, A. Andar, M. O. Riehle, P. Herzyk, C. D. Wilkinson, R. O. Oreffo, Nat. Mater. 2007, 6, 997.

[15] S. Oh, K. S. Brammer, Y. S. Li, D. Teng, A. J. Engler, S. Chien, S. Jin, Proc. Natl. Acad. Sci. U. S. A 2009, 106, 2130.

[16] J. Huang, S. V. Grater, F. Corbellini, S. Rinck, E. Bock, R. Kemkemer, H. Kessler, J. Ding, J. P. Spatz, Nano Lett. 2009, 9, 1111.

[17] V. Dumas, A. Rattner, L. Vico, E. Audouard, J. C. Dumas, P. Naisson, P. Bertrand, J Biomed. Mater. Res. A 2012, 100, 3108.

[18] C. Liang, H. Wang, J. Yang, Y. Cai, X. Hu, Y. Yang, B. Li, H. Li, C. Li, X. Yang, ACS Appl. Mater. Interfaces 2013, 5, 8179.

[19] T. Shinonaga, M. Tsukamoto, G. Miyaji, Opt. Express 2014, 22, 14696.

[20] E. Rebollar, I. Frischauf, M. Olbrich, T. Peterbauer, S. Hering, J. Preiner, P. Hinterdorfer, C. Romanin, J. Heitz, Biomaterials 2008, 29, 1796.

[21] X. Wang, C. A. Ohlin, O. Lu, J. Hu, Biomaterials 2008, 29, 2049.

[22] X. Wang, C. A. Ohlin, O. Lu, J. Hu, J. Biomed. Mater. Res. A 2006, 78,746

[23] B. Zhu, O. Zhang, O. Lu, Y. Xu, J. Yin, J. Hu, Z. Wang, Biomaterials 2004, 25, 4215.

[24] B. Zhu, O. Lu, J. Yin, J. Hu, Z. Wang, J. Biomed. Mater. Res. Part B, Appl. Biomater. 2004, 70, 43.

[25] M. Bolle, S. Lazare, J. Appl. Phys. 1993, 73, 3516.

[26] P. Slepička, O. Neděla, J. Siegel, R. Krajcar, Z. Kolská, V. Švorčík, eXPRESS Polym. Lett. 2014, 7, 459.

[27] P. Slepička, E. Rebollar, J. Heitz, V. Švorčík, Appl. Surf. Sci. 2008, $254,3585$.

[28] E. Rebollar, J. R. Vazquez de Aldana, I. Martin-Fabiani, M. Hernandez, D. R. Rueda, T. A. Ezquerra, C. Domingo, P. Moreno, M. Castillejo, Phys. Chem. Chem. Phys.: PCCP 2013, 15, 11287.

[29] P. Slepička, O. Neděla, P. Sajdl, Z. Kolská, V. Švorčík, Appl. Surf. Sci. 2013, 285P, 885.

[30] W. A. Loesberg, J. te Riet, F. C. van Delft, P. Schon, C. G. Figdor, S. Speller, J. J. van Loon, X. F. Walboomers, J. A. Jansen, Biomaterials 2007, 28, 3944.

[31] M. Ventre, F. Causa, P. A. Netti, J. R. Soc., Interface R. Soc. 2012, 9, 2017.

[32] K. Kulangara, Y. Yang, J. Yang, K. W. Leong, Biomaterials 2012 , 33, 4998.

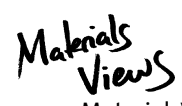

